\title{
Medical Marijuana Effects in Movement Disorders, Focus on Huntington Disease; A Literature Review
}

\author{
Edward Akinyemi ${ }^{1}$, Gavin Randhawa ${ }^{1}$, Victor Longoria $^{1}$ and Rana Zeine ${ }^{1,2}$ \\ ${ }^{1}$ Saint James School of Medicine, Basic Medical Sciences, 1480 Renaissance Drive, Park Ridge, IL 60068 USA; \\ ${ }^{2}$ KEAN University, School of Natural Sciences, Biology Department, 1000 Morris Ave., Union, NJ 07083 USA
}

\begin{abstract}
Purpose: We aimed to comprehensively evaluate the effects of medical marijuana on symptoms that are relevant to movement disorders with a focus on Huntington disease (HD). Methods: A systematic review by literature search through PubMed and EBSCO electronic databases was conducted for relevant studies reported after 2002 on the effects of medical marijuana or cannabis use on tremor, spasm, spasticity, chorea, sleep quality and HD-specific rating scales. Study selection, quality assessment and data extraction was performed by three reviewers. Outcome measures were changes in psychomotor, and sleep related symptoms. The methodological quality of the included studies was evaluated. Results: A total of 22 studies were reviewed. There was strong evidence for significant improvement in the neurologic symptoms of spasms, tremors, spasticity, chorea, and quality of sleep following treatment with medical marijuana. Analysis of specific motor symptoms revealed significant improvement after treatment in tremors and rigidity. Furthermore, all pretreatment and post-treatment measures indicated a significant increase in average number of hours slept. Conclusion: Larger scale studies are warranted to test the benefits of medical marijuana in HD patients. In the meanwhile, clinicians may consider prescribing medical marijuana as part of their strategy for better symptomatic treatment of patients with HD.
\end{abstract}

Received, June 14, 2020; Revised, June 24, 2020; Accepted, October 8, 2020; Published, October 14, 2020

Corresponding Author: Rana Zeine, MD, PhD, MBA, Adjunct Professor, KEAN University, Biology Department, School of Natural Sciences, 1000 Morris Ave., Union, NJ 07083 USA, Email: rzeine@kean.edu; ranazeine@ gmail.com; Mobile: (917) 715 9604

\section{INTRODUCTION}

Neurodegenerative diseases are characterized by a loss of neurons and neuropathological lesions distributed in particular regions of the central nervous system. Huntington disease (HD) is an autosomal dominant inherited neurodegenerative disease caused by an elongated CAG repeat (36 repeats or more) in the huntingtin gene on the short arm of chromosome 4p16.3 $(1,2)$. In HD, there is neuronal loss in the neostriatum, most markedly in the caudate nucleus, and progressing through the putamen (1). Clinically, HD is characterized by worsening involuntary choreic movements, behavioral and psychiatric disturbances, and dementia (2). Psychomotor processes become severely retarded as patients experience psychiatric symptoms and cognitive decline (2). The prevalence of HD in the Caucasian population is estimated at $1 / 10,000$ -
$1 / 20,000$ with mean age of onset at $30-50$ years (2).

Cannabidiol (CBD) is regarded as a compound with therapeutic potential against neurodegenerative and hyperkinetic disorders in view of its neuroprotective effects (3). The endocannabinoid system has been implicated in a broad range of physiological functions such as cognition, mood, motor control, feeding behaviors, and pain (4). The clinical manifestation of movement disorders includes motor symptoms such as resting tremors, rigidity (cogwheel...), akinesia, bradykinesia, loss of righting reflex, chorea, gait disturbances (shuffling gait...), spasticity, and loss of automatic movement, retrocollis, impaired eye movement (downward gaze), pseudobulbar palsy; as well as autonomic dysfunction, cognitive impairment, and depression (1). Preclinical research suggests that cannabinoids 
have symptomatic and neuroprotective potential for a variety of neurologic conditions- including movement disorders $(3,4)$. Marijuana contains around 60 pharmacologically active compounds known as "cannabinoids" (5).

Studies have shown that nonpsychoactive cannabidiol is well tolerated and safe in humans even at high doses (6). Cannabis strains high in CBD content have been used for treatment of patients with intractable seizures, and to relieve symptoms in patients with chronic pain, arthritis, tremors, dementia, post-traumatic stress disorder, and in patients undergoing chemotherapy $(6,7)$. The medical properties of CBD that have been demonstrated in animal studies include antiemetic, anticonvulsant, antipsychotic, anti-inflammatory, antioxidant, anti-cancer, anxiolytic, and anti-depressant effects (7). As of July 2019, 33 states and the District of Columbia in the United States of America have enacted laws allowing marijuana use to treat certain medical conditions (8).

The most common cause of death in HD is pneumonia, followed by suicide (2). In this study, we focus on the effects of medical marijuana on the symptoms of HD including emotional turmoil (depression, apathy, irritability, anxiety, obsessive behavior), cognitive loss (inability to focus, plan, recall or make decisions; impaired insight), and physical deterioration (weight loss, involuntary movements, diminished coordination, difficulty walking, talking, and swallowing) (9).

\section{METHODS}

A systematic review was conducted by literature search through PubMed and EBSCO electronic databases. The text words "marijuana", "cannabis", "THC", "medical marijuana", "CBD", "cannabidol", "Nabilone", "Sativex®", with the use of the Boolean operator "AND" the terms "Huntington disease", "chorea", "rigidity", "psychomotor decline", "cognitive impairment", "tremor" "gait disturbance", "akinesia", "bradykinesia", "retrocollis" and "depression" were used to identify relevant studies discussing the effectiveness of medical marijuana in patients with HD.
The inclusion criteria were the following: 1) must be a scholarly or peer-reviewed source, 2) a relevant article published after 2002, and 3) articles published in the English language only. Exclusion criteria were the following: 1) publications potentially used for marketing purposes, 2) articles in foreign languages, 3) articles dated prior to 2002 .

Outcome measures included any changes in symptoms such as choreic movements, chorea, rigidity, tremors, psychomotor decline, cognitive impairment, and depression. The quality of evidence was assessed by scoring the articles according to the following rating scheme: (1) properly conducted randomized clinical trial, (2) well-designed controlled trial without randomization or prospective comparative cohort study, (3) case-control study or retrospective cohort study, (4) cross-sectional study or case series, (5) case reports or opinion of respected authorities.

\section{RESULTS}

All together 50 relevant reports were identified, 43 through direct and 7 by indirect searches. After cutting the redundancies, 27 full-text articles were assessed, from which 22 were found eligible for inclusion.

The outcomes data were extracted from studies conducted on populations with several conditions including multiple sclerosis (MS), parkinson disease (PD), fibromyalgia, posttraumatic stress disorder (PTSD) and HD. Effects of cannabis use or medical marijuana treatments were tabulated by signs and symptoms of relevance to $\mathrm{HD}$ including spasm and spasticity (Table 1), tremor (Table 2), sleep quality (Tables 1 and 3), chorea, motor and dystonia subscales on the Unified Huntington's Disease Rating Scale (UHDRS) which assesses motor function, cognitive function, behavioral abnormalities, and functional capacity (Table 4), and biochemical markers in animal models (Tables 5 and 6). 
Table 1: Effects of medical marijuana on spasticity

\begin{tabular}{|c|c|c|c|}
\hline Study & Year & Findings & Formulations \\
\hline $\begin{array}{l}\text { Zajicek et al. } \\
\text { Randomized } \\
\text { Controlled Trial } \\
\text { (10) }\end{array}$ & 2003 & $\begin{array}{l}630 \text { MS patients were enrolled in a randomized, } \\
\text { placebo-controlled clinical trial at } 33 \text { centers in the } \\
\text { UK. There was evidence of a treatment effect on } \\
\text { patient-reported spasticity and pain }(\mathrm{p}=0.003) \text {, with } \\
\text { improvement in spasticity reported in } 61 \%(\mathrm{n}=121 \text {, } \\
95 \% \text { CI } 54.6-68.2), 60 \%(\mathrm{n}=108,52.5-66.8) \text {, and } \\
46 \%(\mathrm{n}=91,39.0-52.9) \text { of participants on cannabis } \\
\text { extract, } \Delta^{9}-\mathrm{THC} \text {, and placebo, respectively }(10) \text {. }\end{array}$ & $\begin{array}{l}\text { Oral cannabis extract capsules } \\
\text { containing } 2.5 \mathrm{mg} \Delta^{9} \text {-THC equivalent } \\
\text { and } 1.25 \mathrm{mg} \mathrm{CBD} \text { and }<5 \% \text { other } \\
\text { cannabinoid vs } \Delta^{9} \text {-THC alone }\end{array}$ \\
\hline $\begin{array}{l}\text { Vaney et al. } \\
\text { Randomized } \\
\text { Controlled Trial } \\
\text { (11) }\end{array}$ & 2004 & $\begin{array}{l}57 \text { MS patients were enrolled in a prospective } \\
\text { randomized, double-blind, placebo-controlled, } \\
\text { crossover study in Switzerland. Treatment consisted } \\
\text { of cannabis-extract capsules standardized to } 2.5 \mathrm{mg} \\
\text { tetrahydrocannabinol (THC) and } 0.9 \mathrm{mg} \text { cannabidiol } \\
\text { (CBD). In } 37 \text { patients who received } 90 \% \text { of their } \\
\text { prescribed dose (THC and CBD), significant } \\
\text { improvements in spasm frequency were observed } \\
(\mathrm{p}=0.013)(11) \text {. }\end{array}$ & $\begin{array}{l}\text { Cannabis-extract capsules standardized } \\
\text { to } 2.5 \mathrm{mg} \text { THC and } 0.9 \mathrm{mg} \mathrm{CBD}\end{array}$ \\
\hline $\begin{array}{l}\text { Brady et al. } \\
\text { Open-label pilot } \\
\text { study } \\
(12)\end{array}$ & 2004 & $\begin{array}{l}21 \text { MS patients were recruited for treatment with } \\
\text { cannabis-based extracts and data from } 15 \text { were } \\
\text { evaluated in the UK. Urinary urgency, incontinence, } \\
\text { and nocturia decreased significantly }(\mathrm{p}<0.05) \text { and } \\
\text { patient self-assessment of pain, spasticity and quality } \\
\text { of sleep improved significantly }(\mathrm{p}<0.05)(12) \text {. }\end{array}$ & $\begin{array}{l}\triangle 9 \text {-THC and CBD } 2.5 \mathrm{mg} \text { of each per } \\
\text { spray for eight weeks followed by } 2.5 \\
\text { mg THC-only per spray for a further } \\
\text { eight weeks }\end{array}$ \\
\hline $\begin{array}{l}\text { Novotna et al. } \\
\text { Randomized } \\
\text { Controlled Trial } \\
\text { (13) }\end{array}$ & 2011 & $\begin{array}{l}572 \text { MS patients were enrolled in a randomized, } \\
\text { double-blind, placebo-controlled, parallel-group, } \\
\text { enriched-design study. Results showed significant } \\
\text { improvements in spasticity Numeric Rating Scale } \\
\text { (NRS), Spasm Frequency Score and Sleep } \\
\text { Disturbance following treatment with nabiximols } \\
(\text { Sativex®) }(\mathrm{p}<0.001)(13) \text {. }\end{array}$ & $\begin{array}{l}\left.\text { Nabiximols (Sativex }{ }^{\circledR}\right) \text { study } \\
\text { medication was delivered using a pump } \\
\text { action oromucosal spray. Each } 100-\mu l \\
\text { actuation of active medication delivered } \\
2.7 \mathrm{mg} \text { THC and } 2.5 \mathrm{mg} \text { CBD to the oral } \\
\text { mucosa. Subjects were restricted to a } \\
\text { maximum of } 12 \text { sprays in any } 24-\mathrm{h} \\
\text { period. }\end{array}$ \\
\hline
\end{tabular}

Table 2: Effects of medical marijuana on tremor

\begin{tabular}{|c|c|c|c|}
\hline Study & Year & Findings & Formulations \\
\hline $\begin{array}{l}\text { Venderova et al. } \\
\text { Cross-sectional study } \\
\text { (14) }\end{array}$ & 2004 & $\begin{array}{l}\text { Of } 339 \text { PD patients surveyed, } 25 \% \\
\text { reported Cannabis use and, of those, } 31 \% \text { reported } \\
\text { improvement of resting tremor. Patients using } \\
\text { cannabis for at least } 3 \text { months reported significant } \\
\text { improvement in resting tremors }(\mathrm{p}<0.01)(14) \text {. }\end{array}$ & $\begin{array}{l}\text { Determined patients' personal use } \\
\text { of cannabis by survey questions and } \\
\text { correlated change in symptoms with } \\
\text { concentrations of } 11 \text {-nor- } \delta-9 \text { - } \\
\text { THCOOH in urine }\end{array}$ \\
\hline $\begin{array}{l}\text { Lotan et al. } \\
\text { Case-control study } \\
\text { (15) }\end{array}$ & 2014 & $\begin{array}{l}22 \text { PD patients attending the motor disorder clinic of } \\
\text { a tertiary medical center in Israel, who were } \\
\text { evaluated on the motor Unified Parkinson Disease } \\
\text { Rating Scale at baseline and } 30 \text { minutes after } \\
\text { smoking cannabis, were found to have significant } \\
\text { improvement in tremor }(\mathrm{p}<0.001) \text {, bradykinesia } \\
(\mathrm{p}<0.001) \text { and rigidity }(\mathrm{p}=0.004)(15) \text {. }\end{array}$ & Smoking cannabis 0.5 grams \\
\hline
\end{tabular}


Table 3: Effects of cannabis use on sleep quality

\begin{tabular}{|c|c|c|c|}
\hline Study & Year & Findings & Formulations \\
\hline $\begin{array}{l}\text { Fiz et al. } \\
\text { Cross-sectional } \\
\text { (16) }\end{array}$ & 2011 & $\begin{array}{l}28 \text { fibromyalgia patients surveyed in Spain } \\
\text { reported no significant changes in overall sleep } \\
\text { quality between cannabis-users and non-users on } \\
\text { the Pittsburgh Sleep Quality Index (PSQI) (16). }\end{array}$ & $\begin{array}{l}\text { Determined patients' personal use of } \\
\text { cannabis by survey questions probing } \\
\text { patterns of smoking and eating recreational } \\
\text { cannabis (hashish or marijuana) }\end{array}$ \\
\hline $\begin{array}{l}\text { Tringale and } \\
\text { Jensen } \\
\text { Cohort Study } \\
\text { (17) }\end{array}$ & 2011 & $\begin{array}{l}\text { Amongst } 166 \text { subjects analyzed in a focused, } \\
\text { retrospective cohort study from two cannabis } \\
\text { clinics in Southern California (Ventura and San } \\
\text { Clemente), there was a significant decrease in } \\
\text { total time to fall asleep after the use of cannabis } \\
(\mathrm{p}=0.001)(17) \text {. }\end{array}$ & $\begin{array}{l}\text { Oral, pipe, bong, vaporizer, and joints route } \\
\text { of administration of cannabis. Use per } \\
\text { week up to } 20 \text { grams. }\end{array}$ \\
\hline $\begin{array}{l}\text { Cameron et al. } \\
\text { Cohort study } \\
\text { (18) }\end{array}$ & 2014 & $\begin{array}{l}101 \text { subjects from a correctional population with } \\
\text { PTSD in Ontario, Canada reported a significant } \\
\text { increase in mean number of hours slept from } 5.0 \\
\text { [SD 1.4] pretreatment, to } 7.2 \text { [SD } 1.2] \\
\text { posttreatment }(\mathrm{p}<0.001)(18) .\end{array}$ & $\begin{array}{l}\text { Synthetic Nabilone } 4.0 \mathrm{mg} \text { given in powder } \\
\text { form with water }\end{array}$ \\
\hline
\end{tabular}

Table 4: Effects of medical marijuana in Huntington disease patients

\begin{tabular}{|c|c|c|c|}
\hline Study & Year & Findings & Formulations \\
\hline $\begin{array}{l}\text { Curtis and Rickards } \\
\text { Case report } \\
\text { (19) }\end{array}$ & 2006 & $\begin{array}{l}\text { A } 43 \text {-year-old female HD patient in the UK reported } \\
\text { improvements in behavior and reduction of chorea } \\
\text { maintained by daily dosage of Nabilone (19). }\end{array}$ & $\begin{array}{l}\text { Nabilone, Synthetic 9-keto } \\
\text { cannabinoid, } 1 \text { mg capsule per day }\end{array}$ \\
\hline $\begin{array}{l}\text { Curtis et al. } \\
\text { Randomized } \\
\text { Controlled Trial } \\
\text { (20) }\end{array}$ & 2009 & $\begin{array}{l}44 \mathrm{HD} \text { patients were enrolled in a double-blind, } \\
\text { placebo-controlled, cross-over study of nabilone }(1 \text { or } \\
2 \mathrm{mg}) \text { versus placebo in the UK. Results } \\
\text { demonstrated significant improvement in chorea } \\
(\mathrm{p}=0.009) \text { and neuropsychiatric index }(\mathrm{p}=0.04) \text {; and a } \\
\text { trend for improvement in behavior score }(\mathrm{p}=0.06) \\
(20) .\end{array}$ & Nabilone 1 or 2 mg capsule \\
\hline $\begin{array}{l}\text { Saft et al. } \\
\text { Case-control study } \\
\text { (21) }\end{array}$ & 2018 & $\begin{array}{l}7 \text { HD patients in Europe were evaluated before and } \\
\text { after the start of cannabinoids without any other } \\
\text { changes in medication. Their Unified Huntington's } \\
\text { Disease Rating Scale (UHDRS) motor } \\
\text { score improved from } 70.9 \text { [SD 25.5] to 60.6 [SD 26.9] } \\
\text { ( } \mathrm{p}=0.018) \text {, and the dystonia subscore improved from } \\
12.3 \text { [SD 4.0] to } 8.9 \text { [3.6] ( } \mathrm{p}=0.0180)(21) \text {. }\end{array}$ & $\begin{array}{l}\text { Sativex® } 12 \text { sprays or Dronabinol } \\
4-4-5 \text { drops }(9.1 \mathrm{mg}) \text { or Sativex }{ }^{\circledR} 7 \\
\text { sprays or Dronabinol } 2-2-1 \text { drops } \\
(3.6 \mathrm{mg}) \text { or Dronabinol } 2-0-2 \mathrm{drops} \\
(2.8 \mathrm{mg}) \text { or Nabilone } 0.5 \mathrm{mg}-0-1 \mathrm{mg} \\
\text { or Dronabinol } 1-1-1 \text { drops }(2.2 \mathrm{mg})\end{array}$ \\
\hline $\begin{array}{l}\text { López-Sendón } \\
\text { Moreno et al. } \\
\text { Randomized } \\
\text { Controlled Trial } \\
\text { (21) }\end{array}$ & 2016 & $\begin{array}{l}26 \text { patients were enrolled in a double-blind, } \\
\text { randomized, placebo-controlled, cross-over pilot } \\
\text { clinical trial with Sativex®in Spain. } 24 \text { completed the } \\
\text { trial which showed no differences on the motor } \\
\text { subscore of the Unified Huntington's Disease Rating } \\
\text { Scale }(p=0.286)(22) \text {. }\end{array}$ & $\begin{array}{l}\text { Both Sativex }(\circledR) \text { and placebo were } \\
\text { dispensed as an oral spray, to be } \\
\text { administered up to } 12 \text { sprays/day for } \\
12 \text { weeks. }\end{array}$ \\
\hline
\end{tabular}


Table 5: Loss of striatal type 1 cannabinoid receptors in Huntington-like animal model

\begin{tabular}{|c|c|c|c|}
\hline Study & Year & Findings & Formulations \\
\hline $\begin{array}{l}\text { Blazquez et al } \\
\text { Experimental } \\
\text { Observational Study } \\
\text { (23) }\end{array}$ & 2010 & $\begin{array}{l}\text { Pharmacological activation of CB1 cannabinoid } \\
\text { receptors ameliorates Huntington's disease-like } \\
\text { symptomatology, neuropathology and molecular } \\
\text { pathology in R6/2 (Huntington-like) mice (23). } \\
\text { Expression of the endocannabinoid-deactivating } \\
\text { enzyme fatty acid amide hydrolase (FAAH) is } \\
\text { higher in symptomatic ( } 8 \text { - to 12-week-old) R6/2 } \\
\text { mice than in their wild-type littermates (23). }\end{array}$ & $\begin{array}{l}\text { THC } 2 \mathrm{mg} / \mathrm{kg} \text { body weight per day } \\
\text { intraperitoneally }\end{array}$ \\
\hline
\end{tabular}

Table 6: Results reporting the recovery of $\mathrm{N}$-acetyl-aspartate/Choline (NAA/Cho) in mice: Reduced NAA/Cho levels possibly reflect neuronal and mitochondrial dysfunction/damage

\begin{tabular}{|c|c|c|c|}
\hline Study & Year & Findings & Formulations \\
\hline $\begin{array}{l}\text { Valdeolivas et al } \\
\text { Experimental } \\
\text { Observational Study } \\
\text { (24) }\end{array}$ & 2017 & $\begin{array}{l}\text { R6/2 and wild-type mice were housed in rooms with } \\
\text { controlled photoperiod with free access to standard } \\
\text { food and water. Sativex } ®-\text {-like combination of } \\
\text { phytocannabinoids treatment completely reversed } \\
\text { the reduction in NAA/Cho }(\mathrm{p}<0.005)(24) \text {. }\end{array}$ & $\begin{array}{l}\Delta 9-\mathrm{THC}-\text { and CBD-enriched } \\
\text { botanical extracts combined in a } \\
\text { Sativex } \AA-\text { like ratio } 1: 1(4.5 \mathrm{mg} / \mathrm{kg} \\
\text { equivalent to } 3 \mathrm{mg} / \mathrm{kg} \text { of pure } \mathrm{CBD} \\
+\Delta 9-\mathrm{THC})\end{array}$ \\
\hline
\end{tabular}

Studies have demonstrated that Fatty acid amide hydrolase (FAAH), an anandamidedegrading enzyme that deactivates endocannabinoids, is upregulated in striatal brain tissue from symptomatic Huntington disease-like $\mathrm{R} 6 / 2$ mice, as well as in Huntington disease patients (23).

NAA/Cho (N-acetyl-aspartate/Choline) levels were shown to be reduced in Huntington disease-like mice, possibly reflecting neuronal and mitochondrial dysfunction/damage (24). Treatment with either a broad-spectrum cannabinoid, or combinations of cannabinoids with complementary profiles, have been found to delay progression in an experimental Huntington disease model, and to preserve the integrity of striatal neurons demonstrating that a Sativex®like combination of phytocannabinoids treatment completely reversed the reduction in NAA/Cho $(\mathrm{p}=<0.005)(24)$.

\section{DISCUSSION}

A systematic review was conducted to evaluate the strength of evidence for the efficacy of medical marijuana in alleviating the symptoms that manifest in movement disorders that are particularly relevant in Huntington disease. The eligible studies included 5 randomized placebocontrolled clinical trials, 2 case-control studies, 2 cross-sectional studies, 2 cohort studies, 2 experimental observational studies, 1 open-label pilot study, and 1 case report. The studies of highest quality were the 5 randomized placebo/controlled trials which included a sum total of 1,329 human subjects. The human studies reviewed demonstrated therapeutic effects for medical marijuana in the management of movement disorder symptomatology including the use of Sativex®, which is an oral spray that contains a combination of tetrahydrocannabinol and cannabidiol, and Nabilone, which is a synthetic cannabinoid capsule that is a selective agonist for CB1 and CB2 receptors $(4,25)$. It is assumed that the effects demonstrated by data extracted from the studies which utilized standardized pharmaceutical formulations would be more clinically reliable than those from survey studies which collected self-reported accounts of cannabis use. Furthermore, since pain is also prevalent in Huntington disease patients, the use of medical marijuana could be helpful for them in light of evidence that cannabinoid-based pharmacotherapies might be effective 
for management of chronic pain (26). It would be expected that any benefits experienced by patients would have been longer lasting after ingestion as compared to inhalation.

Although the majority of studies showed statistically significant results favoring the use of medical marijuana, especially for improving motor symptoms and quality of sleep, the number of Huntington disease patients who were available to participate in these studies was a sum total of 78, and it was necessary to examine the effects seen in patients diagnosed with other diseases in which the same type of symptoms exist. As such, the findings of decreased spasticity were demonstrated primarily by measurements in patients with the autoimmune demyelinative disease multiple sclerosis (Table 1). The findings of reduced tremor were demonstrated primarily by assessements in patients with the nigrostriatal neurodegenerative parkinson disease (Table 2). The findings of improved sleep quality were derived from populations of respondents with either the chronic pain disorder fibromyalgia, or the anxiety disorder PTSD, or miscellaneous conditions for which they sought treatment at a cannabis clinic (Table 3). The findings that were shown in patients with the basal ganglial neurodegenerative Huntington disease were improvements in chorea, improvements in the neuropsychiatric index, and trends for improvements in the Unified Huntington's Disease Rating Scale motor score, the dystonia subscore and behavior score (Table 4).

The animal studies reviewed included experimental observations following activation of $\mathrm{CB} 1$ receptors by THC that demonstrate a protective role of the endocannabinoid system against the development and progression of symptoms in R6/2 murine models for Huntington-like disease $(22,23)$.

\section{CONCLUSION}

The observed or reported improvements in the symptoms of movement disorders are consistent with the principal pharmacological effects of THC and CBD. Alleviation of spasticity, tremors, chorea and dystonia might be attributed to the muscle relaxant and analgesic effects of both
THC and CBD. Improvements in sleep quality, behavioral and neuropsychiatric indices could be attributable to the anxiolytic, neuroprotective, anti-oxidant, anticonvulsant, and anti-psychotic activities of CBD. Large scale, randomized, clinical trials, perhaps international collaborative efforts, are warranted to test the use of medical marijuana more widely in HD patient populations, and who may be at various stages of disease progression. Acknowledging the need for determining that the therapeutic benefits shall outweigh any long term risks, we nevertheless recommend that physicians consider prescribing medical marijuana as adjunctive treatment for symptomatic relief to slow the progression or reverse spasms, tremor, spasticity, chorea, dystonia, behavioral, neuropsychiatric and sleep disturbances in patients with Huntington disease.

\section{ACKNOWLEDGEMENTS}

We thank Mr. Edward Carter for his contributions to the research proposal at the initial phase of this project. Authors have no conflict of interest regarding the content of this paper.

\section{REFERENCES}

1. Hedreen JC, Roos RAC., Trinucleotide Repeat Disorders, Huntington's Disease, chapter 5 in Dickson DW (ed.), Neurodegeneration: The Molecular Pathology of Dementia and Movement Disorders, ISN Neuropath Press, Basel, pp 229-241, 2003.

2. Roos RA. Huntington's disease: a clinical review. Orphanet J Rare Dis, 2010; 20:5-40. doi: 10.1186/17501172-5-40

3. Iuvone T, Esposito G, Filippis DD, Scuderi C, Steardo L. Cannabidiol: A Promising Drug for Neurodegenerative Disorders? CNS Neurosci Ther, 2009; 15(1): 65-75. doi: 10.1111/j.17555949.2008.00065.x

4. Kluger B, Triolo P, Jones W, Jankovic J. The therapeutic potential of cannabinoids for movement disorders. Mov Disord, 2015; 30(3), 313-327. doi: 10.1002/mds.26142

5. Koppel BS, Brust JC, Fife T, Bronstein J, Youssof S, Gronseth G, Gloss D. Systematic review: Efficacy and safety of medical marijuana in selected neurologic disorders: Report of the Guideline Development Subcommittee of the American Academy of Neurology. Neurology. 2014; 82(17): 1556-1563. doi: 10.1212/WNL.0000000000000363

6. Savage SR, Romero-Sandoval A, Schatman M, Wallace M, Fanciullo G, Mccarberg B, Ware M. Cannabis in Pain Treatment: Clinical and Research Considerations. J Pain, 2016; 17(6):654-668. doi: 10.1016/j.jpain.2016.02.007 
7. Fernández-Ruiz J, Sagredo O, Pazos MR, García C, Pertwee R, Mechoulam R, Martínez-Orgado J. Cannabidiol for neurodegenerative disorders: important new clinical applications for this phytocannabinoid? $\mathrm{Br}$ J Clin Pharmacol, 2013; 75(2):323-333. doi: 10.1111/j.1365-2125.2012.04341.x.

8. ProCon.org. Legal Medical Marijuana States and DC; Laws, Fees, and Possession Limits. July 2019; Available from https://medicalmarijuana.procon.org/legalmedical-marijuana-states-and-dc/

9. National Institute of Neurological Disorders and Stroke (NINDS). Huntington's Disease: Hope Through Research. NIH, 2020. Available from https://www.ninds.nih.gov/Disorders/PatientCaregiver-Education/Hope-ThroughResearch/Huntingtons-Disease-Hope-Through

10. Zajicek J, Fox P, Sanders H, Wright D, Vickery J, Nunn A, Thompson A. Cannabinoids for treatment of spasticity and other symptoms related to multiple sclerosis (CAMS study): multicenter randomised placebo-controlled trial. Lancet, 2003; 362(9395): 1517-1526. doi:10.1016/s0140-6736(03)14738-1

11. Vaney C, Heinzel-Gutenbrunner M, Jobin P, Tschopp F, Gattlen B, Hagen U, . . Reif, M. Efficacy, safety and tolerability of an orally administered cannabis extract in the treatment of spasticity in patients with multiple sclerosis: a randomized, double-blind, placebocontrolled, crossover study. Mult Scler, 2004; 10(4):417-424. doi:10.1191/1352458504ms1048oa

12. Brady CM, Dasgupta R, Dalton C, Wiseman OJ, Berkley KJ, Fowler CJ. An open-label pilot study of cannabisbased extracts for bladder dysfunction in advanced multiple sclerosis. Mult Scler, 2004; 10(4):425-433. doi:10.1191/1352458504ms1063oa

13. Novotna A, Mares J, Ratcliffe S, Novakova I, Vachova $\mathrm{M}$, Zapletalova $\mathrm{O}, \ldots$. Davies P. A randomized, doubleblind, placebo-controlled, parallel-group, enricheddesign study of nabiximols* (Sativex®), as add-on therapy, in subjects with refractory spasticity caused by multiple sclerosis. Eur J Neurol, 2011; 18(9):11221131. doi:10.1111/j.1468-1331.2010.03328.x

14. Venderová K, Růžička E, Voříšek V, Višňovský P. Survey on cannabis use in Parkinson's disease: Subjective improvement of motor symptoms. Mov Disord, 2004; $\quad$ 19(9): $1102-1106$. doi:10.1002/mds.20111

15. Lotan I, Treves TA, Roditi Y, Djaldetti R. Cannabis (Medical Marijuana) Treatment for Motor and NonMotor Symptoms of Parkinson Disease. Clin Neuropharmacol, 2014; $\quad 37(2)$ : 41-44. doi:10.1097/wnf.0000000000000016

16. Fiz J, Durán M, Capellà D, Carbonell J, Farré M. Cannabis Use in Patients with Fibromyalgia: Effect on Symptoms Relief and Health-Related Quality of Life. PLoS ONE, 2011; 6(4): doi:10.1371/journal.pone.0018440
17. Tringale R, Jensen C. Cannabis and insomnia. O'Shaughnessy's, The Journal of Cannabis in Clinical Practice, 2011 (Autumn); 31-32. Available from http://files7.webydo.com/92/9209805/UploadedFiles/5 E9EC245-448E-17B2-C7CA-21C6BDC6852D.pdf

18. Cameron C, Watson D, Robinson J. Use of a Synthetic Cannabinoid in a Correctional Population for Posttraumatic Stress Disorder-Related Insomnia and Nightmares, Chronic Pain, Harm Reduction, and Other Indications. J Clin Psychopharmacol, 2014; 34(5):559564. doi:10.1097/jcp.0000000000000180

19. Curtis A, Rickards H. Nabilone Could Treat Chorea and Irritability in Huntington's Disease. J Neuropsychiatry Clin Neurosci, 2006; 18(4):553-554. doi:10.1176/appi.neuropsych.18.4.553

20. Curtis A, Mitchell I, Patel S, Ives N, Rickards H. A pilot study using nabilone for symptomatic treatment in Huntington's disease. Mov Disord, 2009; 24(15):22542259. doi: $10.1002 / \mathrm{mds} .22809$

21. Saft C, Von Hein SM, Lücke T, Thiels C, Peball M, Djamshidian A., . . . Seppi K. Cannabinoids for Treatment of Dystonia in Huntington's Disease. J Huntington Dis, 2018; 7(2):167-173. doi:10.3233/JHD170283

22. López-Sendón Moreno JL, García Caldentey J, Trigo Cubillo P, Ruiz Romero C, García Ribas G, Alonso Arias MAA, ... García de Yébenes Prous J. A doubleblind, randomized, cross-over, placebo-controlled, pilot trial with Sativex ${ }^{\circledR}$ in Huntington's disease. J Neurol, 2016; 263(7): 1390-1400. doi:10.1007/s00415-0168145-9

23. Blázquez C, Chiarlone A, Sagredo O, Aguado T, Pazos MR, Resel E., . . . Guzmán M. Loss of striatal type 1 cannabinoid receptors is a key pathogenic factor in Huntington's disease. Brain, 2010; 134(1):119-136. doi:10.1093/brain/awq278

24. Valdeolivas S, Sagredo O, Delgado M, Pozo M, Fernández-Ruiz, J. Effects of a Sativex®-Like Combination of Phytocannabinoids on Disease Progression in R6/2 Mice, an Experimental Model of Huntington's Disease. Int J Mol Sci, 2017; 18(4):E684. doi:10.3390/ijms18040684

25. Wissel J, Haydn T, Müller J, Brenneis C, Berger T, Poewe W, Schelosky LD. Low dose treatment with the synthetic cannabinoid Nabilone significantly reduces spasticity-related pain. J Neurol, 2006; 253:1337-1341. doi:10.1007/s00415-006-021-8

26. Yanes JA, McKinnell ZE, Reid MA, Busler JN, Michel JS, Pangelinan MM, ... Robinson JL. Effects of cannabinoid administration for pain: A meta-analysis and meta-regression. Exp Clin Psychopharmacol. 2019; 27(4):370-382. doi: $10.1037 / \mathrm{pha} 0000281$ 